\title{
14. GLASSY AND BASALTIC FRAGMENTS WITHIN GRADED VOLCANICLASTIC SEDIMENTS, EAST MARIANA BASIN, DEEP SEA DRILLING PROJECT LEG $89^{1}$
}

\author{
P. A. Floyd, Department of Geology, University of Keele ${ }^{2}$
}

\begin{abstract}
Graded volcaniclastic sediments deposited by turbidity currents in the basal section at Site 585 are mixed vitric-lithic tuffs and lapilli-stones with minor plagioclase and clinopyroxene crystal fragments. They represent the reworked products of basaltic hyaloclastite accumulations that developed on the flanks and tops of nearly emergent seamounts. They were subsequently swept to the abyssal depths of the southern Mariana Basin by turbitity currents, along with minor reef debris. Vesicles in glassy clasts are on average very small (0.1-0.2 mm diameter), although their volumes, as a percentage of the enclosing glass, are relatively high and suggest a maximum depth of initial lava intrusion of $<400 \mathrm{~m}$. A shallow-water environment for the hyaloclastites is indicated by the commonly associated shallow-water faunal debris and ooids. There is no clear evidence of epiclastic or pyroclastic material associated with the hyaloclastites.

Glass, rarely preserved as sideromelane, is generally replaced by palagonite or smectites, and ranges from highly vesicular aphyric to moderately vesicular phyric types, with various assemblages of olivine, plagioclase, and clinopyroxene microphenocrysts and megaphenocrysts. Lithic clasts exhibit a range of textures-from opaque quench-textured tachylite glass to hypocrystalline and holocrystalline basalts-which are commonly plagioclase- or plagioclase-clinopyroxene-phyric. Correlation of primary petrographic features between vitric and lithic clasts and textures, based on cooling history, allows the identification of five "lava types," each of which represents an extrusive episode. All the volcaniclastics are pervasively altered, with the development of palagonite, various colored smectites, celadonite, and zeolites typi$\mathrm{cal}$ of the lower zeolite facies. Two phases of alteration are recognized: submarine alteration after initial fragmentation, and subsequent alteration during burial after transportation to abyssal depths.
\end{abstract}

\section{INTRODUCTION}

A major aspect of intraplate volcanism during the Cretaceous was the synchronic development of numerous large subaerial edifices and seamounts throughout the central and western Pacific Ocean. Because volcanism demonstrably was widespread, developed on basement of variable age, and was of long duration (generally considered to encompass the period from $\sim 115$ to $70 \mathrm{Ma}$ ), its generation is incompatible with normal "hotspot" theories of intraplate volcanism (e.g., Watts et al., 1980; Larson and Schlanger, 1981; Schlanger and Premoli Silva, 1981; Haggerty et al., 1982). A consequence of the edifice-building volcanism is that fragmented volcanic debris is shed off the sides of the volcanoes and carried by mass flow into the adjacent abyssal areas. Coring at many Pacific Ocean DSDP sites, including Site 585 (this volume) in the East Mariana Basin (Fig. 1), has recovered Cretaceous volcaniclastic sediments derived from volcanic edifices (e.g., Larson, Moberly, et al., 1975; Schlanger, Jackson, et al., 1976; Larson, Schlanger, et al., 1981). The association of volcanogenic and biogenic components found in such turbidite sequences has been extensively used to reconstruct the volcanic and tectonic development of the adjacent area (e.g., Winterer, 1973). In general terms, three phases in the evolution of a seamount are recognized from the sequential development of associated turbidites, as illustrated by Kelts and Arthur (1981, fig. 13): (1) initial con-

\footnotetext{
${ }^{1}$ Moberly, R., Schlanger, S. O., et al., Init. Repts, DSDP, 89: Washington (U.S. Govt. Printing Office)

2 Address: Dept. of Geology, University of Keele, Staffordshire ST5 5BG, U.K.
}

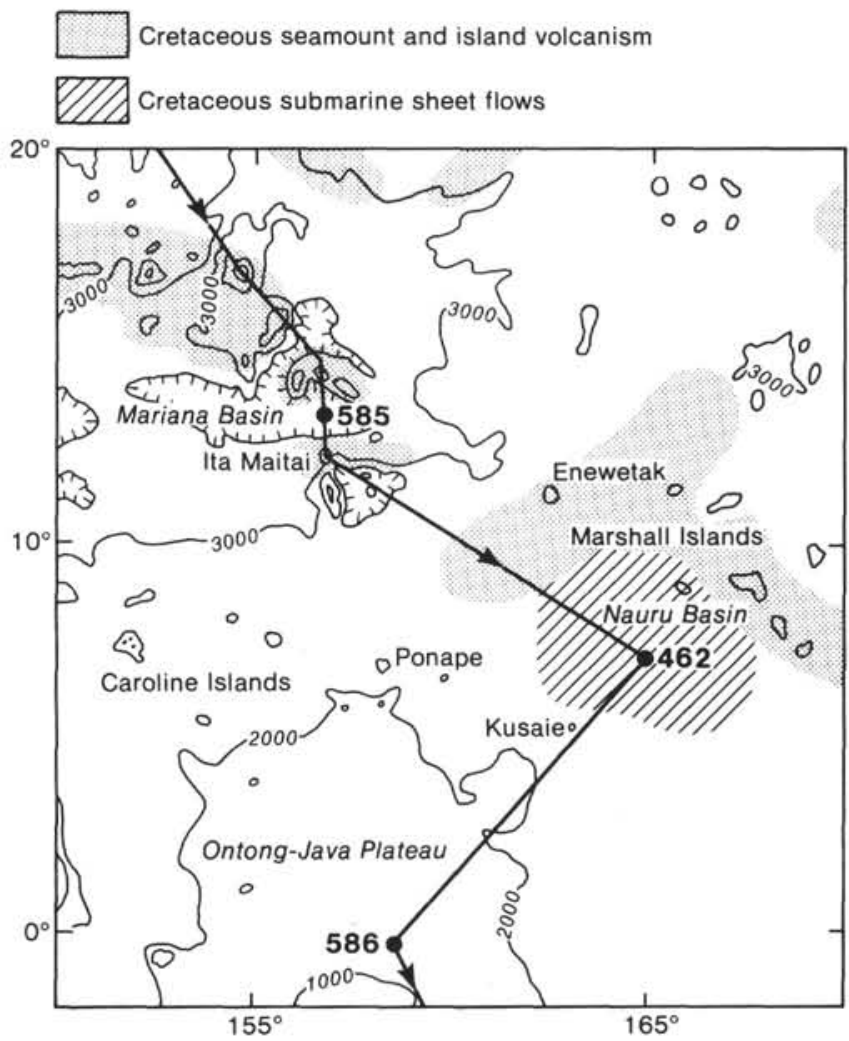

Figure 1. Location of Site 585 in the Mariana Basin of the western Pacific and distribution of Cretaceous intraplate volcanism (Winterer, 1973; Larson and Schlanger, 1981). 
struction of submarine edifice (massive volcanogenic flows), (2) further edifice building until emergent subaerial cone developed with growth of surrounding reef (mixed volcanogenic and shallow-water biogenic debris), and (3) subsidence and development of pelagic carbonate cap (pelagic flows only). The turbidites drilled at Site 585 are typical of the last two phases (site chapter geologic history, this volume).

This paper describes the general features and petrography of glassy, lithic, and crystal clasts found in the coarse basal portions of graded sequences from the lower parts of Holes 585 and 585A, and documents volcanic development at or near the emergent phase already mentioned. The volcanogenic clasts (especially fresh glass) are important in determining the nature (submarine, subaerial), type (tholeiitic, alkaline), and magmatic evolution (degree of differentiation, phenocryst assemblages) of volcanic activity in the adjacent area. Companion studies (this volume) on the geochemistry of extracted large pebble-sized clasts, fresh glass, and crystal fragments provide additional evidence of magmatic character and genesis.

\section{VOLCANICLASTIC ROCK TYPES}

The full sedimentary sequence at Site $\mathbf{5 8 5}$ is divided into six lithologic units (site chapter, this volume), which, in tectonovolcanic terms, can be subdivided into a stratigraphically lower portion (Unit VI), composed of relatively coarse, graded volcaniclastic turbidites and debris flows (upper Aptian to middle Albian), and an upper portion (Units V to I), composed of fine-grained graded zeolitic claystones (middle Albian to Recent). The sediments of the stratigraphically lower group are dominated by volcanogenic material, and are representative of the Cretaceous edifice-building and emergence phase of activity. Within the upper portion, however, the presence of the alteration products of glass and crystal fragments testify to the periodic occurrence of volcanic activity at a later date during the Late Cretaceous-early Eocene subsidence phase.

In terms of grain size and proportions of clasts (Fisher, 1966), most of the volcaniclastic rocks are fine and coarse vitric and lithic tuffs; vitric and lithic lapillistones occurs in lesser amounts. The distribution of tuffs and lapillistones in the lowermost graded units is governed by gravity separation from the turbidite currents, although within the rarer debris flows fine-grained tuffs are mixed with agglomerated material containing pebble/cobble-sized clasts up to an estimated $15 \mathrm{~cm}$ long. In general, the volcaniclastic sediments are really mixed tuffs composed of variable proportions of glass shards, lithic clasts, and crystal fragments, although crystals comprise only a small proportion (1-10\% by volume, based on point-counting of the sections) relative to the other volcanic components (Fig. 2). In a few cases, highly vitric tuffs with cuspate shards dominate some graded units, and are interpreted as reworked hyaloclastites. In genetic terms, the mixed tuffs are also reworked hyaloclastites dominated by glassy shards, with relatively minor hypocrystalline and holocrystalline basaltic clasts. The lithic clasts can often be related to the associated glass, al-

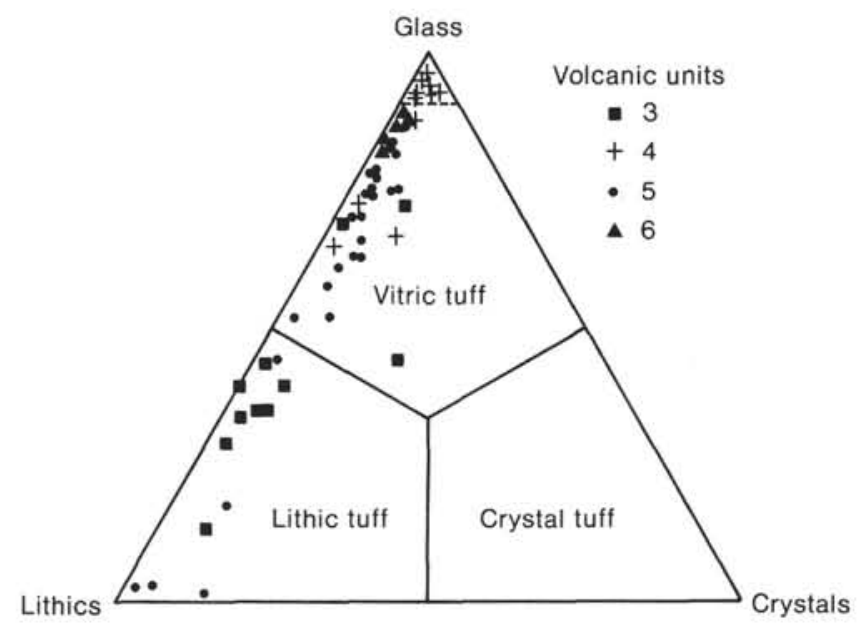

Figure 2. Proportions of vitric, lithic, and crystal fragments in graded volcaniclastic sediments from the basal section at Site 585 .

though the admixture of petrographically different glass and basalt clasts suggest that the turbidity flows sampled material from various hyaloclastite accumulations. The relative proportions of petrographically related glass and lithics in some layers may also imply sampling from different parts of a brecciated submarine lava flow and its associated hyaloclastite carapace. Another typical feature of the mixed tuffs is that they may contain variable proportions of carbonate debris, in particular shallowwater reef material and ooids.

\section{VOLCANIC UNITS}

The volcaniclastic sediments in lithologic Units III to VI are subdivided into seven "volcanic units" (Fig. 3) on the basis of (1) major sedimentological features (e.g., laminated clay-silt sequences, turbidite units, debris flows), (2) the presence of major zones of essentially nonvolcanogenic (i.e., reworked pelagic) sedimentation, and (3) the nature and relative proportions of volcanic clasts in coarse layers. Figure 3 summarizes some of the main volcanic features of the units that will shortly be described in more detail. A tentative volcanologic interpretation is also provided, and demonstrates, in terms of seamount evolution, the division between the emergent or nearly emergent phase (volcanic Units 7 to 3 ) and the subsequent subsidence phase (volcanic Units 2 to 1 ).

Most of this chapter is concerned with the tuffs and lapillistones within the coarse basal parts of graded turbidite sequences comprising volcanic Units 3 through 7 , although Units 1 and 2 are briefly described.

\section{CLAST PARAMETERS AND DISTRIBUTION WITH DEPTH}

\section{Clast Shape}

The majority of clasts are very irregular and angular, the highly vesicular glass shards in particular showing strongly cuspate margins formed by the inner walls of vesicles. Some vesicular glassy fragments are more subangular, and may have been broken during reworking and 


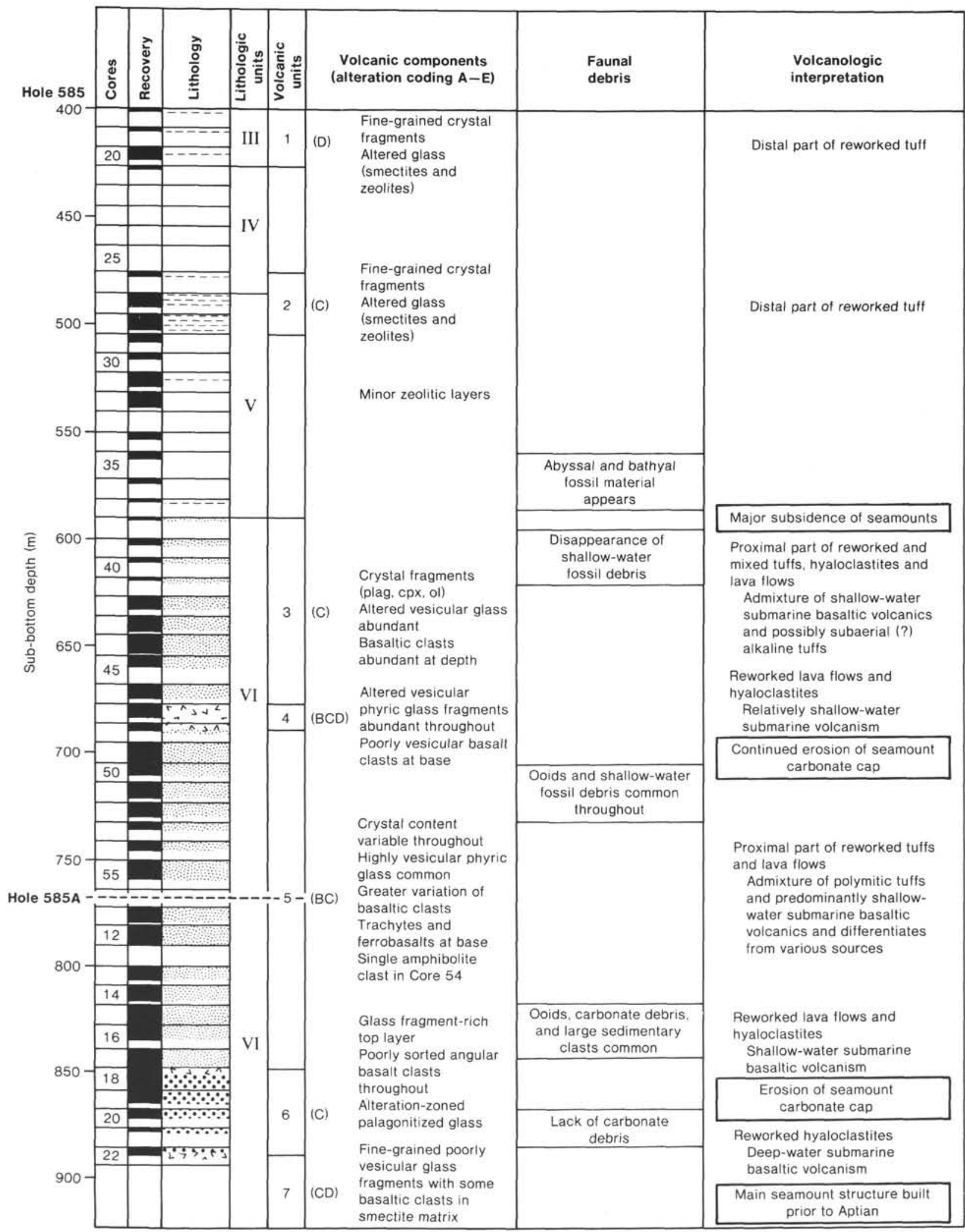

Sedimentoiogical groups containing volcanic material

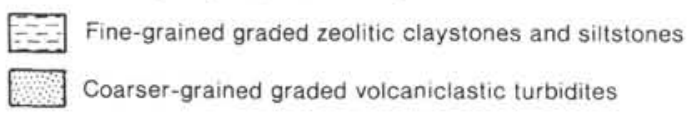

$[\because]$ Graded reworked hyaloclastites
$\because \because$ Volcaniclastic debris flows

Figure 3. Log of volcaniclastic sediments at Site 585 and brief petrographic features of the volcanic units. Significant events in the regional geologic history are enclosed in boxes in the volcanologic interpretation column. 
transportation, with the loss of shard points and delicate extremities. Holocrystalline lithics associated with glass shards tend to be more rounded, with faces produced by both cooling-fracture brecciation and submarine erosion. In general, the degree of angularity attained by volcanic clasts is mainly a function of vesicularity and proportion of glass, and reflects the conditions of formation at the source rather than the effects of mass-flow transportation. Thus, highly vesicular glassy clasts are irregular and shard-like and poorly vesicular glassy basaltic clasts are generally angular to subangular, whereas nonvesicular holocrystalline basaltic clasts tend to be marginally more rounded. The largest basalt clasts in the debris flows often have rounded margins. Crystals may be completely fragmentary and angular in shape or may largely retain their original, often euhedral, prismatic form, with perhaps an irregularly broken termination. Cleavage fragments are generally not very common. The basal portion of a turbidite flow may thus contain a variety of clast shapes, depending on the volcanic components present, although most are angular.

\section{Clast Size}

The length and width (taken at half-length distance) of a large number of glassy and lithic clasts were measured or estimated in the basal portions of the turbidites. Data for the different volcanic units and a frequency distribution for the measured clast length are shown in Figure 4, and a statistical summary is given in Table 1. As shown in Figure 4, the clast shapes in the different units are essentially similar, ranging from equidimensional forms (width: length ratio of $1: 1$ ) to tabular forms (ratio of 1:4) for both glassy and lithic clasts.
The majority of all the clasts are less than $2 \mathrm{~mm}$ long and $1 \mathrm{~mm}$ wide, and on average, marginally larger in the debris flow sequence (volcanic Unit 6). This unit as a whole has considerably larger than usual clasts, which are not accommodated by Figure 4 (ranging from 0.5 to $15 \mathrm{~cm}$ ), although they are relatively uncommon. In general, glassy clasts appear to be larger on average than associated clasts (average glassy clast length $=0.9 \mathrm{~mm}$; lithic clast $=0.7 \mathrm{~mm}$ ), although the size frequency distributions are essentially similar (Fig. 4). Since much of the very fine-grained matrix of the mixed vitric-lithic tuffs is smectite derived from the alteration of minute glassy fragments, the grain-size range of the glass must be extended to lower values than actually measured and, if included, effectively reduces the average clast size relative to the lithic clasts.

\section{Proportion of Clasts}

Glassy clasts, basaltic lithics, and crystal fragments, together with variable proportions of fine-grained smectitic matrix, also derived from original glass, make up the dominant volcanogenic portion of all mixed tuffs. Any other material is biogenic (carbonate debris), and is present in relatively minor proportions (1-5 vol. \%). As seen in Figure 2, volcanic Unit 3 is characterized by a higher proportion of lithic clasts than Unit 5, which is glass-clast-rich. The highly vitric nature of volcanic Units 4, 6, and 7 is also exhibited. The lithic-dominated Unit 5 volcaniclastic are lapillistones from a coarse basal unit in Core 585-54, which has some of the characteristics of a debris flow, within the predominantly turbidite sequence. Figure 5 illustrates the proportions of both volcanogenic and biogenic components as a func-

Table 1. Summary of statistical data on clasts at Site 585 .

\begin{tabular}{|c|c|c|c|c|c|c|c|c|c|c|c|c|}
\hline \multirow{2}{*}{$\begin{array}{c}\text { Sample } \\
\text { (interval in } \mathrm{cm} \text { ) }\end{array}$} & \multirow{2}{*}{$\begin{array}{c}\text { Volcanic } \\
\text { unit }\end{array}$} & \multirow{2}{*}{$\begin{array}{l}\text { Lithologic } \\
\text { type }^{\mathrm{a}}\end{array}$} & \multicolumn{3}{|c|}{ Glass $^{\mathrm{b}}$} & \multicolumn{3}{|c|}{ Lithics $^{b}$} & \multicolumn{4}{|c|}{ Vesicles in glass ${ }^{c}$} \\
\hline & & & $n$ & $\bar{x}$ & $s d$ & $n$ & $\bar{x}$ & $s d$ & $n$ & $\bar{x}$ & $s d$ & Vol. \% \\
\hline $585-46-4,22-27$ & 3 & VT & & 1.0 & & & 0.5 & & 281 & 0.086 & 0.052 & 23 \\
\hline $585-47-4,95-98$ & 4 & $\mathrm{H}$ & & 1.5 & & & 0.8 & & 174 & 0.069 & 0.036 & 13 \\
\hline $585-47-4,136-138$ & 4 & $\mathrm{H}$ & & 1.0 & & & 0.5 & & 127 & 0.056 & 0.027 & 7 \\
\hline $585-47-5,1-5$ & 4 & $\mathrm{H}$ & 57 & 1.18 & 0.68 & 47 & 0.74 & 0.36 & 71 & 0.067 & 0.020 & 8 \\
\hline $585-47$, CC $(6-9)$ & 4 & $\mathrm{H}$ & & 1.5 & & & 0.8 & & 109 & 0.065 & 0.039 & 12 \\
\hline $585-48-1,43-37$ & 4 & VT & & 2.0 & & & 1.5 & & 150 & 0.122 & 0.080 & 25 \\
\hline $585-48-1,108-110$ & 4 & VT & 64 & 1.12 & 0.78 & 34 & 1.02 & 0.95 & 35 & 0.160 & 0.102 & 26 \\
\hline $585-48-1,141-144$ & 4 & vT & & 5.0 & & & 3.0 & & 34 & 0.328 & 0.223 & 48 \\
\hline $585-51-2,135-138$ & 5 & VT & & 1.0 & & & 1.0 & & 60 & 0.084 & 0.039 & 16 \\
\hline $585 \mathrm{~A}-11-3,116-118$ & 5 & VT & 59 & 0.15 & 0.28 & 54 & 0.31 & 0.20 & & & & \\
\hline $585 \mathrm{~A}-13-5,13-17$ & 5 & VT & 197 & 0.69 & 0.65 & 73 & 0.65 & 0.43 & 115 & 0.152 & 0.088 & 44 \\
\hline $585 \mathrm{~A}-14-2,76-79$ & 5 & VL & 56 & 1.12 & 0.71 & 60 & 0.74 & 0.57 & & & & \\
\hline $585 \mathrm{~A}-15-2,89-93$ & 5 & VL & 57 & 1.12 & 0.93 & 42 & 0.73 & 0.77 & 52 & 0.141 & 0.090 & 36 \\
\hline $585 \mathrm{~A}-15-2,146-150$ & 5 & VL & 87 & 0.67 & 0.63 & 66 & 0.71 & 0.66 & & & & \\
\hline $585 \mathrm{~A}-18-7,61-64$ & 6 & VL & 76 & 0.85 & 0.65 & 91 & 0.69 & 0.52 & & & & \\
\hline $585 \mathrm{~A}-19-1,42-45$ & 6 & vT & & 1.5 & & & 1.0 & & 43 & 0.173 & 0.090 & 37 \\
\hline $585 \mathrm{~A}-19-4,22-25$ & 6 & VL & & 1.5 & & & 1.0 & & 200 & 0.170 & 0.098 & 40 \\
\hline $585 \mathrm{~A}-20-1,110-114$ & 6 & VT & & 1.0 & & & 0.5 & & 37 & 0.135 & 0.088 & 30 \\
\hline $585 \mathrm{~A}-21-2,66-69$ & 6 & VL & & 1.5 & & & 1.5 & & 24 & 0.115 & 0.062 & 5 \\
\hline $585 \mathrm{~A}-22-1,126-129$ & 6 & H & 80 & 1.26 & 0.91 & 36 & 1.03 & 0.91 & & & & \\
\hline 585A-22-2, 10-14 & 6 & VT & & 1.2 & & & 1.0 & & 35 & 0.155 & 0.093 & 31 \\
\hline Averages $^{d}$ & & & 733 & 0.89 & 0.7 & 503 & 0.71 & 0.6 & 1547 & 0.11 & 0.07 & 20 \\
\hline
\end{tabular}

${ }^{a}$ Lithologic types: $\mathrm{H}=$ hyaloclastite $_{S \mathrm{~S}}, \mathrm{VT}=$ vitric tuff, $\mathrm{LT}=$ lithic tuff, $\mathrm{VL}=$ vitric lapillistone, $\mathrm{LL}=$ lithic lapillistone.

$\mathrm{b}$ Length of longest axis of glass and lithic clasts, $n=$ number of clasts measured, $\bar{x}=$ average length $(\mathrm{mm}), s d=$ standard deviation. Single value is an average visual estimate only.

c Diameter of vesicles in glass clasts, $n=$ number of vesicles measured, $\bar{x}=$ average apparent diameter $(\mathrm{mm}), s d=$ standard de-

viation, vol. $\%=$ vesicle volume as percentage of glass volume.

d Averages weighted according to total number of measurements in each sample. 

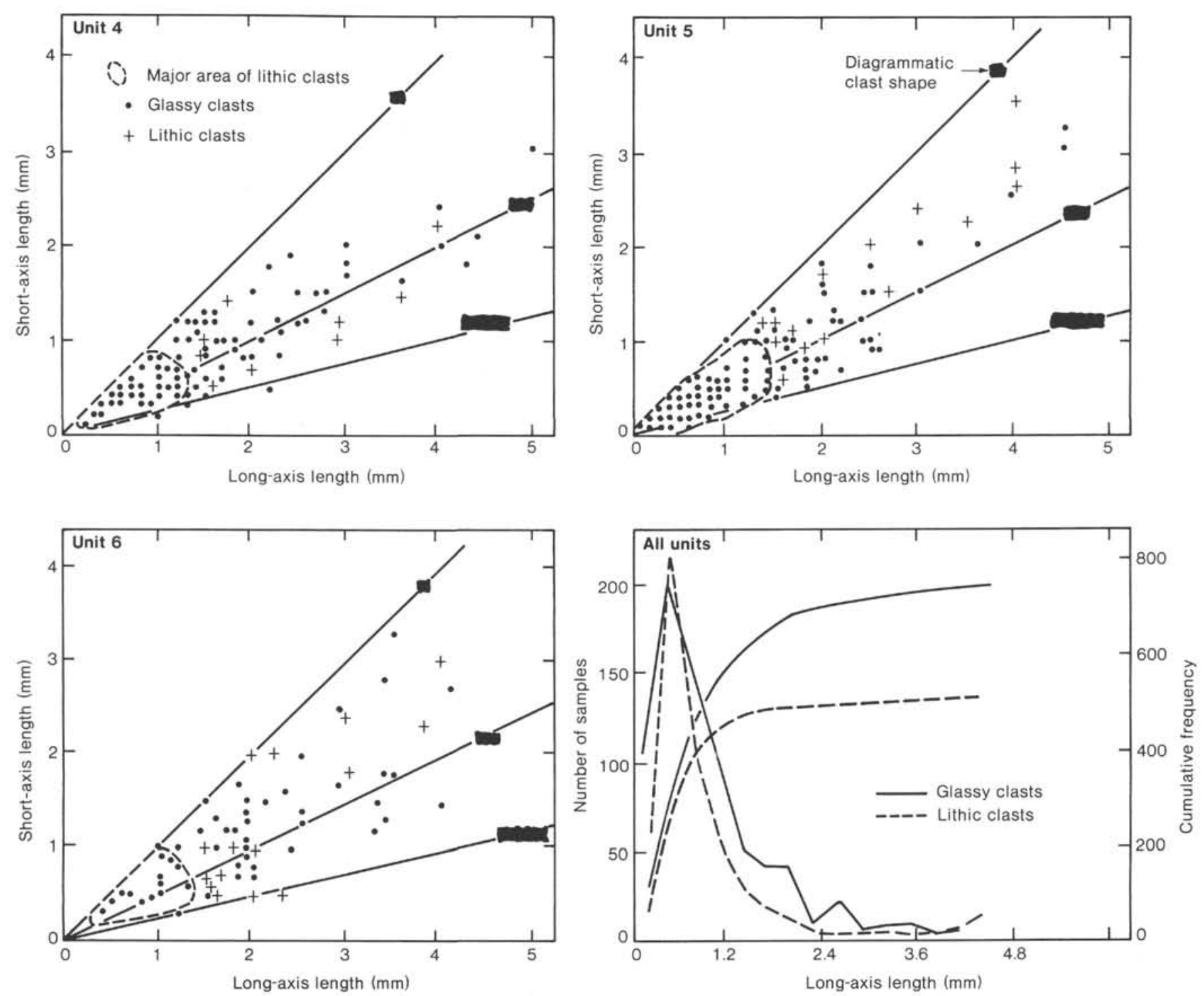

Figure 4. Variation in size of vitric and lithic clasts in volcanic Units 4 to 6 , together with the frequency (number of samples) and cumulative frequency of the longest axis of clasts in the basal portions of turbidite deposits.

tion of depth in volcanic Units 3 to 7 . Although variable, the lower units (Hole 585A) appear more glassy than the upper units (Hole 585), except for the reworked hyaloclastite interval, Unit 4 . The upper units are, on the other hand, generally richer in lithics. Crystal fragments of clinopyroxene and plagioclase are present throughout, fresh plagioclase being common at the base of the sequence, whereas elsewhere clinopyroxene is dominant (Fig. 5).

\section{Vesicle Size}

The apparent diameters of over 1500 circular vesicles in glassy shards throughout volcanic Units 3 to 7 were measured and their volumes calculated and expressed as a percentage of the overall clast volume (Table 1, Fig. 5). The majority of vesicles are apparently very small, with a size distribution that is positively skewed owing to random measurement of sections through spherical vesicles (Fig. 6). In reality, the diameters of the vesicles will be larger than the apparent average of $0.11 \mathrm{~mm}$. However, the measurement range in clasts from any one thin section is often small (Table 1) and unimodal, although some distributions are visibly bimodal (Fig. 5). Bimodal distributions are characteristic of individual clasts rather than of the tuff unit as a whole, because single clasts may exhibit the association of numerous very small vesicles together with much larger ones of fairly uniform size. Although there is considerable overlap in the range of apparent vesicle diameters (Fig. 5), vesicles in the lower part of the sequence tend to be larger $(0.15 \mathrm{~mm}$ diameter) than those in the upper part $(0.07 \mathrm{~mm}$ diameter $)$.

Vesicle shape and size distribution-or, rather, volume percent of vesicles relative to volume of the enclosing glass - are important in determining whether lavas are subaerial or submarine. Flow margins of subaerial lavas are typified by numerous large, often coalesced, irregular vesicles, whereas owing to the hydrostatic pressure, submarine lavas tend to be relatively less vesicular, 


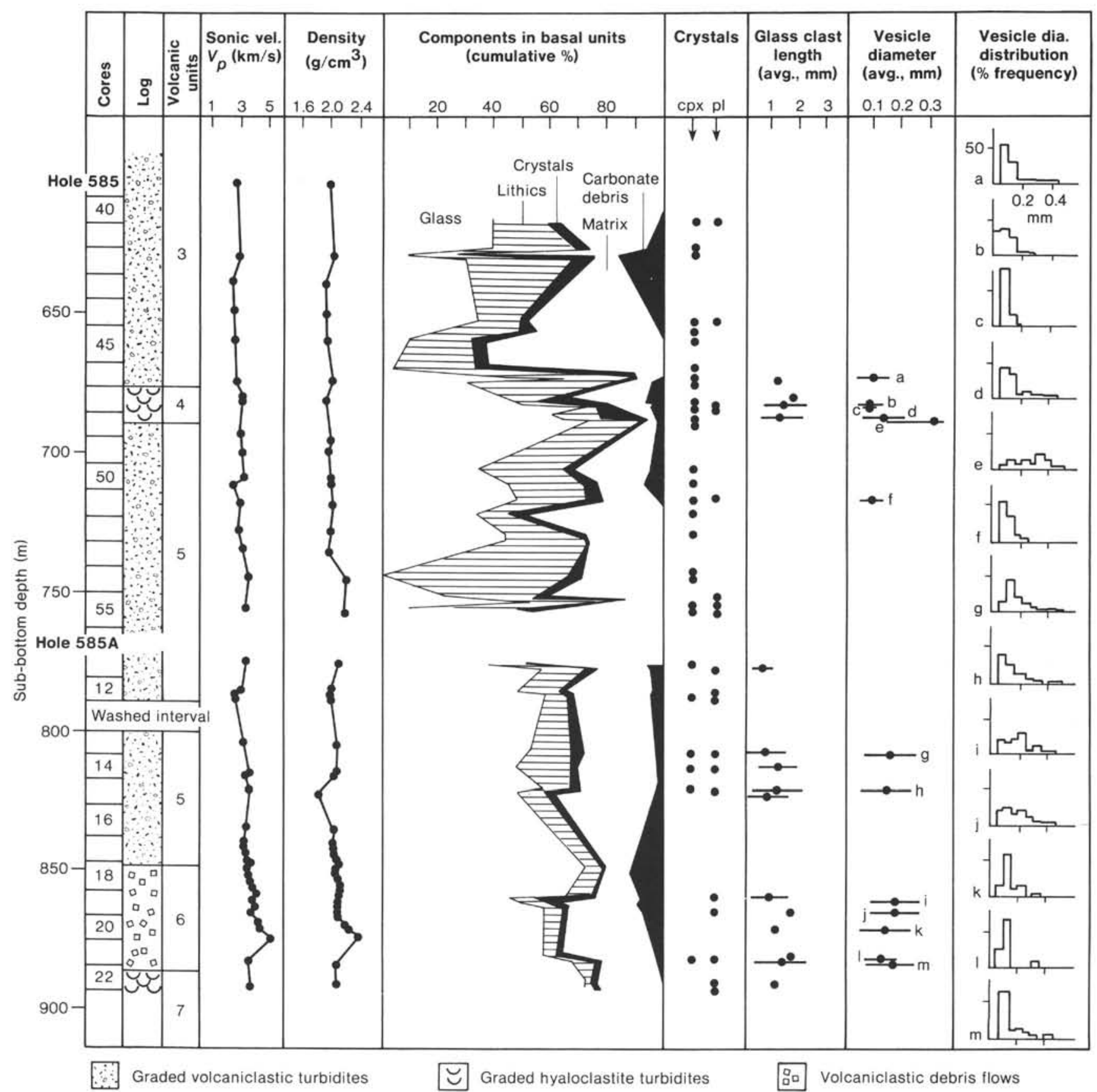

Figure 5. Log of physical parameters, proportion of volcanogenic and biogenic components in volcanic Units 3 to 7 , together with average clast and vesicle size measurements.

with small circular individual vesicles often arranged in zones. Because the hydrostatic pressure increases with depth, vesiculation of rapidly quenched flow margins is restricted, such that, at depths greater than a few hundred meters the range of vesicle volume and size rapidly decreases (Moore and Schilling, 1973; Moore, 1979). These generalizations, however, refer largely to tholeiitic compositions. Some subaqueous alkali basalts may be highly vesicular, reflecting enhanced volatile contents compared with tholeiites. The overall abundance, small size, and circular nature of the vesicles in the glassy clasts examined here clearly indicate that the lavas were submarine and probably extruded at relatively shallow depths. The vesicle volume as percentage of the enclosing glass ranges from 5 to $48 \%$ (Table 1); the higher volumes tend to be at the base of the sequence. Direct application of these data to the approximately linear relationship between vesicle volume and extrusion depth for tholeiitic compositions (Moore, 1979; Moore et al., 1982) indicates that Site 585 lavas may have originally been extruded at between 300 and $600 \mathrm{~m}$ depth. This can only be considered an approximation of the maximum extrusion depth, since the measurement statistics and distribution of the diameters suggest that the actual volumes should be larger. This effect is offset to some extent, however, because when the proportion of apparently non- 


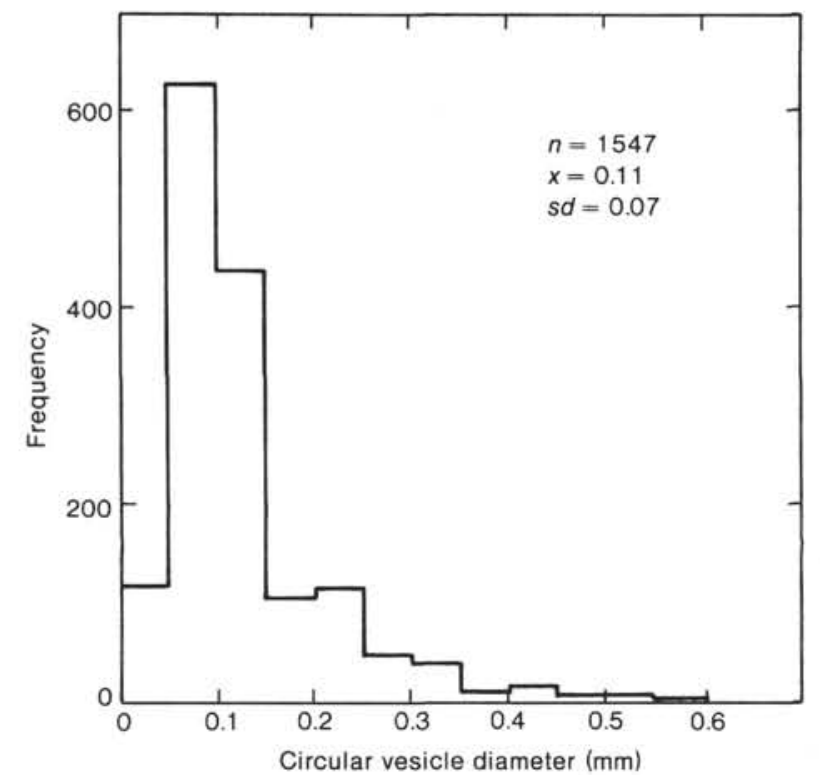

Figure 6. Frequency distribution of apparent vesicle diameters in glassy clasts.

vesicular glass $(\sim 30 \%)$ is taken into account, the overall vesicle volume decreases. An average vesicle volume of $20 \%$ (Table 1), or perhaps higher, indicates a maximum extrusion depth of about $400 \mathrm{~m}$, which, in the light of associated biogenic carbonate and ooids, seems rather deep.

\section{Variation of Physical Parameters with Depth}

Variations with depth of tuff constituents, glassy clast size, and vesicle size distributions are shown in Figure 5. No real systematic changes are apparent, except for a gradual increase with depth in both sonic velocity and wet bulk density. It is not possible to relate any variation to specific volcanic units or volcanic lithologies, except that the increase in density at the base may reflect the higher proportion of large, dense basaltic clasts in volcanic Unit 6 or it may reflect compaction due to burial.

The only other notable feature is the tendency for the stratigraphically lower portion (essentially Hole 585A) to be richer in glassy clasts which generally have larger vesicles and a higher ratio of plagioclase to clinopyroxene crystal fragments. Clast sizes are essentially similar throughout. It must be remembered, however, that these comments refer only to the coarse basal portions of different turbidite units rather than the whole graded sequence.

\section{GENERAL DESCRIPTION OF VOLCANIC UNITS}

Units 1 (Cores 585-15 to 585-20) and 2 (Cores 585-26 to $585-28$ ) constitute various relatively minor volcanogenic layers within zeolitic claystones and siltstones (Fig. 2 ), and will be briefly documented first, before the major volcaniclastic Units 3 to 7 . Units 1 and 2 are both composed essentially of broken, angular crystals and various alteration products of glassy debris. No fresh glass was observed. Crystal fragments are generally untwinned plagioclase (although a few twinned laths had a compo- sition of about $\mathrm{An}_{70}$ ), some alkali feldspar, smectite-replaced olivine microphenocrysts(?), and colorless clinopyroxene. A high proportion of the units are composed of various green and brown smectites and celadonite, probably developed after basaltic glass, and zeolitic fibers (clinoptilolite and phillipsite[?]; identification based on shipboard X-ray diffraction [XRD]) of diagenetic origin. Clinoptilolite is often considered to be a diagenetic alteration product of acidic glass (Coombs, 1958), although in this case it is not obvious what is being replaced, since no original material remains within the fibrous zeolitic matt. The presence of phillipsite suggests low-temperature submarine alteration during diagenesis or burial. Occasionally, individual radiate green smectite nodules and spheres are locally present in the matrix, and represent vesicle infillings released by erosion from glassy clasts.

The fine-grained and graded nature of these and adjacent pelagic units suggests that they represent the distal part of a turbidite flow that sampled and reworked aquagene vitric-crystal tuffs. Zeolitic horizons occur intermittently throughout the stratigraphically higher finegrained portion of Hole 585; if originally developed from glass, they indicate volcanic activity of considerable duration in the area.

\section{Unit 3: Cores 585-38 to $585-46$}

This unit is generally fine-grained and better laminated than subsequent volcaniclastic sediments, and is characterized by interlayering of fine-grained micrite and slightly coarser glass- and lithic-rich volcanogenic material in a smectite matrix. Most of the rocks are reworked, laminated, calcareous zeolite-bearing vitric-lithic tuffs. Throughout the unit, lithic fragments increase in size and become more abundant with depth, whereas the upper sections are vitric clast-dominated. Some finely laminated, brightly colored layers are dominated by orange and yellow smectite, presumably developed from minute glass fragments, which may be variably coated with red hematite. These layers also contain small zeolite spheroids $(0.05-0.1 \mathrm{~mm}$ in diameter) of granular and fibrous clinoptilolite (according to shipboard XRD). The spheroids show a variety of zeolite forms, from completely granular to those having an interior of fibrous radiate zeolite nucleated on a granular rim.

Within the vitric component, sideromelane is generally rare (seen in Section 585-42-3) and palagonite common, although most of the sub-angular vesicular glass fragments are replaced by yellowish to brown fibrous smectite or zeolite. Vesicles are lined with fibrous green smectite which may be replaced by zeolite or, more rarely, by bright green celadonite with minor carbonate. Zoned smectite-infilled vesicles may be seen in the matrix of the tuff; they represent amygdales released from their glassy host by fracturing during transportation. Lithic fragments are dominated by angular $(0.1-1.0 \mathrm{~mm})$, poorly vesicular, plagioclase-phyric tachylite and plagioclase-microphyric granular-textured basalts containing variable proportions of brown smectite-replaced glass. Some of the dark tachylite fragments show incipient quench textures and, in particular, the presence of plagioclase 
microlites and numerous magnetite granules (identified optically). In general the hypocrystalline and holocrystalline basalts are fine-grained and characteristically plagioclase-rich. In one case (Section 585-41,CC), a relatively large (3-mm) quench-textured glassy fragment was observed to enclose a coarser-grained holocrystalline basalt clast; this provides limited evidence of the uptake of previously brecciated flow material by subsequent extrusions. Crystal fragments are also small, consistent with the other clasts, and consist of broken, occasionally twinned fresh plagioclase $\left(\mathrm{An}_{60-70}\right)$, colorless clinopyroxene, and smectite-pseudomorphosed olivine. Pale brown titanaugite and euhedral apatite crystals are rarer constituents, and suggest that some of the volcanism was alkaline. The relatively large size of the broken crystals $(\sim 2 \mathrm{~mm})$ suggests that they are phenocrysts, although the plagioclase is not directly comparable with the microphenocrysts seen in the tachylite fragments.

\section{Unit 4: Core 585-47 to Top Portion of Core 585-48}

This is a thin reworked hyaloclastite unit, about $11 \mathrm{~m}$ thick, characterized by a sequence of graded beds composed predominantly of variably altered vesicular glass fragments. The matrix is made up of fine-grained greenish yellow smectite, opaque granular material, and various replacing fibrous zeolites, the last of which (together with a dark green celadonite) may also replace adjacent clasts. Fossil carbonate debris and ooids are relatively minor, but occur in variable proportions throughout the unit.

Glass clasts are shard-like, and have irregular or cuspate margins formed by the curved interior surfaces of adjacent vesicles. Some preserve sharp-pointed delicate cusps; on others these cusps have been broken off to produce more subrounded glassy fragments. The mixture of variably fragmented glass clasts (and rarer subrounded lithics) suggests either deviation from more than one lava flow or transportation (and differential abrasion) in different flow regimes of the turbidity currents. Glass shards are invariably replaced by golden brown palagonite or yellow smectite, and may be either aphyric or plagioclase-clinopyroxene-phyric. Only in a single example have euhedral olivine microphenocrysts (partially smectite-replaced) been observed in a palagonite fragment (Section 585-48-1). Microphenocrysts of plagioclase in glass are often replaced by bright green pleochroic celadonite. Lithic fragments are subordinate to glass in this unit, but are typically plagioclase \pm clinopyroxene phyric tachylite and various plagioclase-rich basalts, some of which contain pink titanaugite in the matrix. Rare carbonate-bearing vitric tuffs are seen in Section 585$47, \mathrm{CC}$ as individual fragments. Within the smectitic matrix are also large, free-floating, green, fresh clinopyroxene "megacrysts," released from their clasts, that match those seen in the surrounding phyric glass. Partially zeolite-replaced plagioclase megacrysts (and possibly pseudomorphosed olivine phenocrysts) are much less common.

\section{Unit 5: Core Base of 585-48 to Core 585-55 and Cores 585A-11 to 585A-17}

Variably graded volcaniclastic turbidite sequences containing glass, lithic, and crystal fragments in a smectite \pm zeolite matrix make up this unit. Core 585-54, however, appears to be a debris flow with clasts supported by a fine-grained palagonite-smectite matrix, and is thus distinguishable from the rest. Overall, this unit is typified by the presence of various zeolite veinlets throughout, and zeolite-, zeolite-calcite-, and zeolite-analcitelined vugs.

Both glass and lithic basalt clasts are porphyritic with matching phenocrysts assemblages and morphologies. Large free-floating crystal fragments in the matrix (megacrysts) can also be compared directly with those observed in megaphyric vitric and lithic clasts. Within some graded units, various textural gradations can be observed between plagioclase-phyric tachylite, dark plagioclase-rich, quench-textured hypocrystalline basalts, and fine-grained granular holocrystalline basalts. This feature and the similarity of phenocryst assemblages implies that these clasts have all been derived from one or several similar hyaloclastite accumulations. The observed differences between clasts (degree of vesicularity in glass, phenocryst assemblages, variable alteration, different basalt types) suggest, however, that the turbidity current responsible for their transportation also sampled several different fragmented lava flows of variable composition.

Glassy clasts are angular to subrounded, in contrast to those typical of Unit 4, which have cuspate margins. Sideromelane (Section 585A-11-3) is occasionally present, but is usually surrounded by a rim of palagonite. Reddish brown alteration-zoned palagonite is common, although glass clasts are also frequently pseudomorphosed by greenish smectite or zeolite, both of which can be partially replaced by carbonate. Zeolite replacement of both clasts and matrix frequently occurs adjacent to veins of zeolite (commonly natrolite or heulandrite, according to shipboard XRD results). Rarely, deep red isotropic "glass" is seen; its color appears to result from a thin coating of hematite rather than red smectite. Many of the glassy clasts are variably porphyritic, containing fresh clinopyroxene megacrysts, pseudomorphosed olivine megacrysts, and smaller green smectitereplaced plagioclase laths. Lithics are generally poorly vesicular, plagioclase-rich basalts and magnetite-rich dark tachylite. An opaque plagioclase-clinopyroxene-phyric hypocrystalline basalt is the most common type, with all the glass replaced by brown smectite. Other lithics include fine- and coarse-grained holocrystalline basalts and trachytes; some of the former contain olivine microphenocrysts and groundmass purple titanaugite. A single exotic find was a fine-grained epidote amphibolite clast (585-54-2, 65-67 cm), which represents either the sampling of metamorphosed ocean crust (from a submarine fault scarp?) or a basalt metamorphosed at a deep level within the volcanic edifice and subsequently ejected. Some of the larger, angular basaltic clasts may exhibit a thin dark glassy rim, although others (more rounded) have only a portion of glassy margin or none at all. Crystals are generally broken fresh subhedral megacrysts of clinopyroxene and plagioclase, together with green smectite-iddingsite-replaced olivine prisms. All have been released from the associated vitric, and to a lesser extent, lithic, clasts. Broken plagioclase megacrysts and laths may frequently be replaced by coarse-grained blue-green 
celadonite. A few rare flakes of apparently clastic, strongly pleochroic biotite were observed in Core 585A-13; these imply the presence of well-evolved differentiates at the source.

Carbonate reef debris and ooids occur throughout this unit, indicating a shallow-water origin of the sampled hyaloclastites; this is consistent with the relatively high vesicle volume of the associated glassy clasts. Further evidence of their close association in the turbidite source area is provided by the nucleation of ooids on volcaniclastic material, including smectite-replaced glass, tachylite, basaltic clasts, and clinopyroxene crystal fragments.

\section{Unit 6: Cores 585A-18 to Top of Core 585A-22}

This unit contains some of the coarsest volcaniclastic sediments observed, although the top $6.5 \mathrm{~m}$ is composed almost entirely of altered angular to subrounded broken glass fragments (1-3 mm) and constituents of a reworked hyaloclastite. Most of the unit is characterized by the admixture of fine-grained, tabular purple clasts (10-60 mm long), carbonate debris, altered glass fragments, and basaltic clasts of varying size. Most of the basaltic clasts are less than $5 \mathrm{~mm}$ long, although some can reach cobble dimensions; one basaltic clast measured at least $15 \mathrm{~cm}$ across, and was terminated by the core diameter. Since the clasts are poorly sorted and matrixsupported, this unit represents a series of debris flows, and is thus distinct from the graded sequences above it.

The matrix is composed of fine-grained green smectite variably replaced by zeolite. The growth of zeolite (commonly heulandite) and opaline silica on clast margins and also in vugs is a common feature of this unit. Vesicular glassy shards here are yellow-brown palagonite or pale green smectite, both of which may be replaced by matrix zeolites. Sideromelane is rare. Some palagonite shards contain both micro- and megacrystic plagioclase phenocrysts; others are aphyric and also nonvesicular. Lithic clasts are not as varied as in Unit 5 above, although plagioclase-phyric tachylite and hypocrystalline basalts with quench textures are again common. Oliv- ine-phyric basalt and aphyric Fe-rich holocrystalline basalts are also present. Crystal fragments are commonly fresh megacrystic plagioclase rather than clinopyroxene. They are clearly derived from the associated glassy clasts, as illustrated by the partial release of some crystals from their host clast; broken terminations may be observed sticking into the surrounding matrix while the other end of the crystal is held within its clast.

\section{Unit 7: Base of Core 585A-22}

This is a tentative unit the identification of which is based on drilling fragments at the base of Hole 585A. The pieces of rock are.composed almost exclusively of reworked, poorly vesicular palagonitized glass fragments set in a green smectite matrix. Some glass clasts are plagioclase-phyric. Unit 7 is distinct from the unit above in lacking carbonate and basaltic clasts, and represents the sampling of a hyaloclastite accumulation.

\section{PETROGRAPHIC INFERENCES AND CHARACTERSTICS OF CLAST ASSOCIATIONS}

This section describes the primary petrographic features and relations of vitric, lithic, and crystal clasts, some of which are necessarily only inferred, owing to the masking effects of alteration. On the basis of similar phenocryst assemblages and textures, the vitric and lithic clasts are tentatively correlated and assigned to various petrographic "lava types" from which they were initially derived at extrusion. In general, most graded sequences within the volcanic units show an admixture of different petrographic types, and indicate that turbidity currents sampled a number of distinct lava flows and associated hyaloclastite accumulations. Also, the inclusion of material showing varying degrees of alteration and the enclosure of one clast by another suggest the presence of flows of different relative extrusion ages at the turbidity-current source.

A tentative correlation between clasts, shown in Table 2 , indicates the presence of five petrographic "lava types." In each case vitric clasts predominate, and each

Table 2. Correlation of petrographic features characterizing different vitric and lithic clasts.

\begin{tabular}{|c|c|c|c|c|}
\hline $\begin{array}{l}\text { Lava } \\
\text { types }\end{array}$ & Glass & Opaque "glass" & Hypocrystalline basalt & Holocrystalline basalt \\
\hline Aphyric & & & & Aphyric ferrobasalt \\
\hline 1 & $\begin{array}{l}\text { Highly vesicular aphyric } \\
\text { sideromelane }\end{array}$ & $\begin{array}{l}\text { Variable vesicular aphyric } \\
\text { tachylite }\end{array}$ & $\begin{array}{l}\text { Aphyric plagioclase-rich } \\
\text { basalt } \\
\text { Aphyric Ti-augite basalt }\end{array}$ & $\begin{array}{l}\text { Aphyric trachyte with Ti- } \\
\text { augite } \\
\text { Aphyric fine- to medium- } \\
\text { grained Ti-augite basalt }\end{array}$ \\
\hline \multicolumn{5}{|l|}{ Phyric } \\
\hline 2 & $\begin{array}{l}\text { Nonvesicular olivine-mi- } \\
\text { crophyric sideromelane }\end{array}$ & - & - & $\begin{array}{l}\text { Olive-megaphyric Ti-augite } \\
\text { basalt }\end{array}$ \\
\hline 3 & $\begin{array}{l}\text { Poorly to moderately vesicu- } \\
\text { lar plagioclase-, clinopy- } \\
\text { roxene-, and plagioclase- } \\
\text { clinopyroxene-megaphyric } \\
\text { sideromelane }\end{array}$ & $\begin{array}{l}\text { Plagioclase-clinopyrox- } \\
\text { ene-microphyric and } \\
\text { megaphyric tachylite }\end{array}$ & $\begin{array}{l}\text { Plagioclae-clinopyroxene- } \\
\text { megaphyric basalt }\end{array}$ & - \\
\hline 4 & $\begin{array}{l}\text { Moderately vesicular plagio- } \\
\text { clase-microphyric and } \\
\text { megaphyric sideromelane }\end{array}$ & $\begin{array}{l}\text { Plagioclase-microphyric } \\
\text { tachylite, often with } \\
\text { quench crystallites }\end{array}$ & $\begin{array}{l}\text { Plagioclase-phyric basalt, } \\
\text { sometimes with } \\
\text { plagioclase microlites }\end{array}$ & Plagioclase-phyric basalts \\
\hline 5 & $\begin{array}{l}\text { Highly vesicular clinopyrox- } \\
\text { ene-olivine-megaphyric } \\
\text { sideromelane }\end{array}$ & - & - & - \\
\hline
\end{tabular}


type represents a hyaloclastite deposit formed by the rapid quenching of submarine basaltic flows. The presence of subordinate glass-bearing lithics and holocrystalline basalt clasts could indicate the inclusion of fragmented material from the solidified interiors of flows. Most of the lava types appear to be tholeiitic and alkali olivine basalts, the latter of which is suggested by the presence of olivine and titanaugite in the rock matrix. On the basis of dredged material, the association of tholeiitic and alkaline basalts is typical of some seamounts developed on young crust (Batiza, 1980). Many Pacific oceanic islands also show a range of magma compositions, the distribution and temporal sequence of which can change (e.g., from tholeiitic to alkaline) (MacDonald and Katsura, 1964; Moore et al., 1982).

Subaerial edifices of some oceanic islands also contain areally restricted central complexes characterized by the presence of well-differentiated magmas. The general lack of evolved compositions among the Site 585 clasts could imply that the local volcanoes had not developed to that stage of differentiation, and/or that they had not built subaerial structures of any magnitude. The faunal evidence suggests that the clasts were derived from shallow-water lagoonal or reef environments, and if these environments fringed a well-developed emergent island, then some strongly differentiated epiclastic or pyroclastic fallout material might also be expected in the nearshore regions. Site 585 material appears, however, to be exclusively submarine in origin, and the paucity of unequivocal evolved epiclastic debris suggests that the local seamounts did not have much or any subaerial expression and were not particularly evolved magmatically.

Vitric and lithic clasts can conveniently be divided into stages representing a cooling continuum from rapidly quenched clear glass (sideromelane) to opaque glass (tachylite \pm quench textures), hypocrystalline basalt to relatively slowly cooled holocrystalline basalt. All can be variably vesicular, although the basaltic fragments are generally nonvesicular to poorly vesicular (up to $\sim 5 \%$ ) relative to vitric fragments. They may also be aphyric or phyric, with the phyric, clear glassy fragments providing the free-floating crystal fragments in the matrix. A distinction can be made between phenocrysts of different sizes; only the largest $(0.4-0.6-\mathrm{mm}$ long axis, some up to $1.5 \mathrm{~mm}$ ) are preserved as fragments and are referred to here as megacrysts. Clasts characterized by small phenocrysts $(0.05-0.10-\mathrm{mm}$ long axis) are called microphyric, whereas clasts with the larger phenocrysts are megaphyric. Some glass clasts typically exhibit the association of both microphenocrysts and megaphenocrysts of plagioclase; clinopyroxene tends to form megacrysts only.

Sideromelane is relatively rare, although its former presence is indicated by palagonite and/or smectite, which commonly replaces basaltic glass. Opaque clasts, on the other hand, may grade from tachylite into dark smectite-replaced, highly glassy basalts. In several cases, tachylite can be seen to be crowded with minute magnetite granules, and to exhibit spherulitic textures or plumes of crystallites. The presence of numerous crystallites and granules produces dark-colored clasts that have been formed by relatively rapid quenching and constitute a transition to the more crystalline types. Phenocrysts in tachylitic material (with or without quench textures) are similar in type and composition to those in hypocrystalline basalts.

\section{Lava Type 1 (Table 2)}

Although all the vitric and lithic "members" of this petrographic type are aphyric, the crystalline basalts may not necessarily be related to the glass, or indeed to each other, since a number of varieties are exhibited. The glass is typically highly vesicular, shard-like, and generally alteration-zoned palagonite or smectite. All fresh sideromelane clasts observed are aphyric and belong to this lava type. Aphyric tachylite is rare, although hypocrystalline and holocrystalline aphyric plagioclase-rich $\left(\mathrm{An}_{55-60}\right)$ basalts are relatively common. Aphyric basalts may be fine- to medium-grained, granular in texture, and may contain purplish titanaugite prisms in the groundmass. Two other less common aphyric holocrystalline lithics are a magnetite-rich granular basalt and a trachyte exhibiting flow-aligned titanaugite-plagioclase-magnetite crystals. The trachyte and titanaugite-bearing basalt may be genetically related and representative of an alkali basalt lineage.

\section{Lava Type 2}

Only a few clasts of essentially nonvesicular olivine microphyric glass have been found. The euhedral olivines are generally replaced by smectite, and in few cases appear to enclose brownish isotropic ovoids of glass clearly different from the host palagonite. Olivine-phyric holocrystalline lithics are more common, and the presence of titanaugite suggests that they are alkali basalts. Whether they are related to the olivine-microphyric glass is debatable, because olivine occurs in the basalt clast as megacrysts, and may be associated with colorless phenocrystic clinopyroxene.

\section{Lava Type 3}

This and lava type 4 constitute the bulk of all clasts, and provide the megacryst fragments. They may indeed be related, differing as they do only in the proportions of phenocrystic clinopyroxene and microcrysts and megacrysts of plagioclase, all of which may occasionally be seen associated together in some clasts.

Lava type-3 glass is poorly to moderately vesicular sideromelane, and may contain clinopyroxene, plagioclase, or clinopyroxene-plagioclase megacrysts. The typical association of clinopyroxene and plagioclase suggests that the monophenocrystic glass may be chance fragments broken from this type. Many of the free-floating matrix clinopyroxene magacrysts appear to have been released on initial fragmentation of the quenched glass, since they often retain euhedral or subhedral shapes, as exhibited by those enclosed in glassy hosts. Clinopyroxene phenocrysts may sometimes be twinned, although optical zoning is not observed. In the rare instances when plagioclase is not replaced, it is polysynthetically twinned and normally zoned, with cores of about $\mathrm{An}_{70}$. The glassy clasts find their counterpart in the dark clinopyroxene-plagioclase-microphyric and -megaphyric tachy- 
lite and hypocrystalline basalts. Only in one instance has glomerophyric clinopyroxene been seen in tachylite of this lava type.

\section{Lava Type 4}

The moderately vesicular glass is invariably palagonite, forms subangular clasts, and is characterized by the association of both microcrysts and megacrysts of plagioclase. The microcrysts form small laths or forked microlites, whereas the megacrysts are subhedral prisms; both are invariably replaced by greenish smectite, celadonite, or zeolites. Plagioclase-microphyric tachylite, often showing indeterminate quench cystallites, is the commonest opaque clast seen in the volcaniclastic sediments. Plagioclase-phyric hypocrystalline and holocrystalline basalts are the more crystalline representatives of the tachylite, rather than of the two-generation plagioclase glass. The compositions of the plagioclase phenocrysts are difficult to determine accurately, but range from about $\mathrm{An}_{65}$ to $\mathrm{An}_{72}$. The basalts are all fine-grained and poorly vesicular with granular textures, and any glass in them is altered to brownish smectite.

\section{Lava Type 5}

Type 5 is distinguished from the rest by being highly vesicular and strongly porphyritic, and by having the only clasts to show the association of phenocrystic clinopyroxene and olivine. Phenocrysts may constitute up to about $25 \mathrm{vol} . \%$ of the clast, and are often the largest observed, commonly measuring 1.0 to $1.5 \mathrm{~mm}$ along the $c$-axis. One internally fractured and rounded clinopyroxene phenocryst was $2.7 \mathrm{~mm} \times 1.4 \mathrm{~mm}$ and one of the biggest seen. Although apparently no plagioclase phenocrysts are present, this lava type could be related to type 3 (but with the addition of olivine), as no lithic equivalents have been found.

\section{ALTERATION EFFECTS}

The effects of low-grade alteration are seen throughout the volcaniclastics; relatively rare sideromelane and some plagioclase and clinopyroxene megacrysts and matrix crystals in lithics are the only fresh material remaining. Secondary minerals are predominantly various colored smectites, zeolites (clinoptilolite, heulandite, phillipsite, natrolite), analcite, celadonite, carbonates and minor barite, silica and hematite, and abundant palagonite. Representative analyses and a brief review of the chemistry of some of these secondary phases are given by Floyd and Rowbotham (this volume).

There is apparently no systematic change in secondary assemblages with depth that indicates increasing grade, although the upper fine-grained units are characterized by clinoptilolite, whereas the lower graded units contain analcite-phillipsite, which appears to be replaced by heulandite at greater depth. Zeolite veining and zeolite-rimmed vugs become common below 820 m sub-bottom. The ubiquitous occurrence of smectites, zeolites, and analcite indicate zeolite facies of metamorphism, although high-temperature zeolites, as seen in the Tertiary lava pile of eastern Iceland (Walker, 1960; Viereck et al., 1982), have not been recognized. Clinoptilolite and phillipsite are generally characteristic of the lower grades of the zeolite facies, and probably represent alteration temperatures of well below about $60^{\circ} \mathrm{C}$, or perhaps conditions similar to those producing low-grade submarine alteration of the ocean crust. Other secondary minerals, such as smectites, celadonite, and analcite, are stable over the full range of zeolite facies metamorphism (Miyashiro, 1973). Although the overall grade is typically zeolite facies, alteration of the volcaniclastics took place in two stages: (1) soon after initial eruption on the seamount flanks and top, and (2) after transportation into the adjacent abyssal depths and during subsequent burial. Evidence for the initial shallow-water submarine alteration of the hyaloclastites comes from (1) ooids nucleated on smectite-replaced vesicular glass shards, tachylite, and altered basalt clasts, (2) palagonitized glass enclosing smectite-replaced glass clasts, (3) sideromelane enclosing a palagonitized shard with smectite-infilled vesicles, and (4) rare ooids with hematitized rims. Apparently, variable clast alteration took place in this environment before enclosure in the host clast or in ooids that only grow in shallow warm waters. This stage is largely represented by the development of palagonite, smectites, celadonite(?), and minor hematite. On subsequent burial, the volcaniclastics were penetrated by anoxic solutions that precipitated zeolites, analcite, calcite and minor siderite, barite, and silica in veins and vugs. Zeolites replace only rock matrix, phenocrysts, or fill vesicles adjacent to veined or vuggy areas. Zeolite, analcite, and calcite are all later secondary minerals, since they consistently replace earlier smectites, celadonite and palagonitized glass.

Several alteration sites can be recognized: glass in clasts and hypocrystalline basalts, the fine-grained matrix of the clast components, infilled vesicles, microphenocrysts and megaphenocrysts, and late crosscutting veins and vugs.

\section{Glass}

Sideromelane is replaced either by golden brown palagonite or, more commonly by a yellow or green smectite. In some cases palagonite may be replaced by later zeolites. Palagonitized shards may show alteration zoning with greenish yellow interiors and dark brown granular marginal zones which sometimes exhibit a curvilinear network of small cracks. Cracks may penetrate from the brown zone into the paler interior of shards, although the crack width rapidly decreases inward. Smectite replacement of palagonite begins at clast margins or vesicle rims, and is initially granular and poorly birefringent relative to complete smectite pseudomorphs, which are more fibrous or platy. Apart from common yellow or green smectite, a few shards are marginally replaced or coated with hematite. Shards may also be totally replaced by a colorless fibrous zeolite, with which dark green celadonite or carbonate may occasionally be associated. Glass in hypocrystalline clasts is always replaced by a dark brown smectite.

\section{Matrix}

The matrix between clasts is invariably replaced by either fine-grained green smectite or, sometimes, by late platy zeolite and carbonate. Smectite replacement indi- 
cates that the matrix was probably finely comminuted glass.

\section{Amygdales}

Vesicle infillings in glassy shards are zoned with different colored radially oriented smectites, which may exhibit cores of later celadonite or may be composed of zeolite replacing earlier smectite. Zoned infillings may show from two to four zones, which are always very thin ( $\sim 0.01 \mathrm{~mm}$ wide) and fine-grained on the vesicle walls and grade to thicker ( $0.05-0.15 \mathrm{~mm}$ wide), more fibrous zones and finally, in the center, to relatively coarse, fibrous or decussate plates or even, in large vesicles, to a central vacuole. Smectite-zoned amygdales (e.g., in Section 585-481) show color changes from pale yellow (or sometimes very pale green) rims to darker green interiors, with the coarser fibrous zones showing replacement embayments in the earlier, finely fibrous zone. Interiors of smectite-dominated vesicles may be composed of bright green celadonite concordantly filling the vesicle core without apparent replacement of the initial smectite. Some shards may have vesicles entirely composed of bright bluish green pleochroic celadonite or fibrous zeolites \pm carbonate, the latter of which appear to have replaced the original smectite and/or celadonite. Compositional changes in vesicles indicate a change in depositing solutions from relatively reducing $\mathrm{Mg}$-rich to marginally oxidizing and $\mathrm{Fe}$ - and $\mathrm{K}$-rich. $\mathrm{CO}_{2}$ activity is very low throughout, except during late zeolitization by solutions rich in $\mathrm{Na}$ and $\mathrm{Ca}$.

\section{Microphenocrysts and Megaphenocrysts}

Olivine phenocrysts are always replaced by brown or dark green smectites, although a single occurrence showed a latticework of celadonite veinlets traversing a fibrous zeolite pseudomorph. Both plagioclase microphenocrysts and megaphenocrysts in glassy clasts are characteristically replaced by a coarse-grained pleochroic bluish green or bright green celadonite. Replacement by green smectite, zeolites, and analcite is not so common, although this may be seen in plagioclase-phyric lithics rather than in glassy clasts. Fresh and partly altered plagioclase may coexist in lithic clasts, whereas in altered glassy clasts plagioclase is always replaced. Clinopyroxene is the only phenocryst phase that remains unaltered.

\section{Veins and Vugs}

Vein material has not been studied in any detail, but it clearly causes a second phase of alteration in the host rock adjacent to the vein. Veins and vugs are composed of various zeolites (natrolite, heulandite, minor phillipsite) that may be associated with analcite, calcite-silica, and minor barite.

\section{SUMMARY AND CONCLUSIONS}

1. Site 585 volcaniclastic sediments and included reef debris were derived from the tops and flanks of nearly emergent seamounts via turbidity currents and debris flows, which carried them to abyssal depths in the southern Mariana basin. The coarse-grained, stratigraphical- ly lower volcanogenic graded units represent the shallow-water submarine erosion of volcanic edifices built before the late Aptian. Subsequent mid-Cretaceous subsidence is recorded by the fine-grained biogenic-volcanogenic upper section at Site 585 .

2 . The volcaniclastic sediments are mixed vitric-lithic tuffs and lapillistones, with minor crystal fragments derived mainly from the vitric clasts during initial lava quenching and fragmentation. They are divided into volcanic units on the basis of the relative proportion of vitric to lithic clasts and the mode of sediment transportation. Genetically, the graded volcaniclastics are the reworked products of various basaltic hyaloclastite accumulations developed in shallow-water environments $\$ 400 \mathrm{~m}$ deep. This is based on the high vitric content of the tuffs, their highly vesicular nature, the volume percent of vesicles, and the associated shallow-water faunal debris and ooids. There is no unequivocal evidence of epiclastic or pyroclastic debris; the volcaniclastics all appear to be of submarine origin.

3. A comparison of primary petrographic features and textures allows the vitric and lithic clasts to be correlated and grouped into five basaltic "lava types," one aphyric and four phyric. A particular lava type, upon submarine extrusion, was rapidly quenched and fragmented, with the attendant accumulation of mainly glassy shards, released phenocrysts, and some fine-grained basalts derived from the more slowly cooled flow interiors. The admixture of clasts of different lava type within any one graded volcaniclastic unit indicates that the turbidity current sampled a series of different flows of various compositions and ages. The glass and lithics are invariably basaltic in composition, and are more often than not porphyritic, with variable assemblages of olivine, plagioclase, and clinopyroxene microphenocrysts and megaphenocrysts. Trachytes with flow-oriented plagioclase and titanaugite are rare, more evolved variants, as are magnetite-rich ferrobasalts. Many of the basalts appear to be tholeiitic, although olivine, titanaugite, and apatite in some lithics indicate the presence of alkali basalts also. The association of tholeiitic and alkali basalts is characteristic of many seamounts in the Pacific area.

4. The volcaniclastic sediments are pervasively altered. Development of palagonite, various colored smectites, celadonite, and zeolites is extensive; carbonate, sulphate, silica, and iron oxides are of limited occurrence. Sideromelane is relatively rare; most glassy shards are replaced by alteration-zoned palagonite or yellow-green smectites. Glass in quenched vitreous lithics is tachylitic or replaced by brown smectite. Except for clinopyroxene, phenocrysts are replaced by greenish smectites, celadonite, or, occasionally, zeolites. Typically, vesicles are concentrically zoned by radiate fibrous smectites, and sometimes have an interior of coarse-grained celadonite. Zeolite veining and zeolite-rimmed vugs, with analcite-phillipsite at upper levels and heulandite in the lower, are relatively common in the section below $820 \mathrm{~m}$ subbottom. Secondary assemblages indicate the lower zeolite facies, although two phases of alteration are represented: (1) submarine weathering at the initial site of hyaloclastite development (smectites, celadonite, minor 
Fe-oxides), and (2) during burial after transportation by turbidity currents (zeolites, carbonates, silica).

\section{ACKNOWLEDGMENTS}

This work benefited considerably from shipboard discussions of Pacific volcaniclastic sediments with Dr. R. Moberly and Dr. J. Haggerty. I acknowledge Dr. R. Batiza and Dr. J. Sinton for their reviews.

\section{REFERENCES}

Batiza, R., 1980. Origin and petrology of young oceanic central volcanoes: Are most tholeiitic rather than alkalic? Geology, 8:477-482.

Coombs, D. S., 1958. Zeolitized tuffs from the Kuttung glacial beds near Seaham, New South Wales. Aust. J. Sci., 21:18-38.

Fisher, R. V., 1966. Rocks composed of volcanic fragments and their classification. Earth Sci. Rev., 1:287-298.

Haggerty, J. A., Schlanger, S. O., and Premoli Silva, I., 1982, Late Cretaceous and Eocene volcanism in the southern Line Islands and implications for hot-spot theory. Geology, 10:433-437.

Kelts, K., and Arthur, M. A., 1981. Turbidites after ten years of deepsea drilling-wringing out the mop? In Warme, J. E., Douglas, R. G., and Winterer, E. L. (Eds.), The Deep Sea Drilling Project-A Decade of Progress. Soc. Econ. Paleontol. Mineral. Spec. Publ., 32:91-127.

Larson, R. L., Moberly, R., et al., 1975. Init. Repts. DSDP, 32; Washington (U.S. Govt. Printing Office).

Larson R. L., and Schlanger, S. O., 1981. Geological evolution of the Nauru Basin and regional implications. In Larson, R. L., Schlanger, S. O., et al., Init. Repts. DSDP, 61: Washington (U.S. Govt. Printing Office), 841-862.

Larson, R. L., Schlanger, S. O., et al., 1981. Init. Repts. DSDP, 61: Washington (U.S. Govt. Printing Office).
MacDonald, G. A., and Katsura, T., 1964. Chemical composition of Hawaiian lavas. J. Petrol., 5:83-133.

Miyashiro, A., 1973. Metamorphism and Metamorphic Belts: London (Halsted Press, John Wiley and Sons).

Moore, J. G., 1979. Vesicularity and $\mathrm{CO}_{2}$ in mid-ocean ridge basalt. Nature (London), 282:250-253.

Moore, J. G., Clague, D. A. and Nornark, W. R., 1982. Diverse basal types from Loihi Seamounts, Hawaii. Geology, 10:88-92.

Moore, J. G., and Schilling, J. G., 1973. Vesicles, water and sulphur in Reykjanes Ridge basalts. Contrib. Mineral. Petrol., 41:105-118.

Schlanger, S. O., Jackson, E. D., et al., 1976. Init. Repts. DSDP, 33: Washington (U.S. Govt. Printing Office).

Schlanger, S. O., and Premoli Silva, I., 1981. Tectonic, volcanic and paleogeographic implications of redeposited reef faunas of Late Cretaceous and Tertiary age from the Nauru Basin and the Line Islands. In Larson, R. L., Schlanger, S. O., et al., Init. Repts. DSDP, 61: Washington (U.S. Govt. Printing Office), 817-827.

Viereck, L. G., Griffin, B. J., Schmincke, H. -U., and Pritchard, R. G., 1982. Volcaniclastic rocks of the Reyderfjordus drill hole, eastern Iceland. 2: Alteration. J. Geophys. Res., 87:6459-6476.

Walker, G. P. L., 1960. Zeolite zones and dyke distribution in relation to the structure of the basalts in eastern Iceland. J. Geol., 68: 515-p528.

Watts, A. B., Bodine, J. H., and Ribe, N. M., 1980. Observations of flexure and the geological evolution of the Pacific Ocean basin. Nature, 283:532-537.

Winterer, E. L., 1973. Regional problems. In Winterer, E. L., Ewing, J. I., et al., Init. Repts. DSDP, 17: Washington (U.S. Govt. Printing Office), 911-922.

Date of Initial Receipt: 9 March 1984 Date of Acceptance: 4 July 1984 

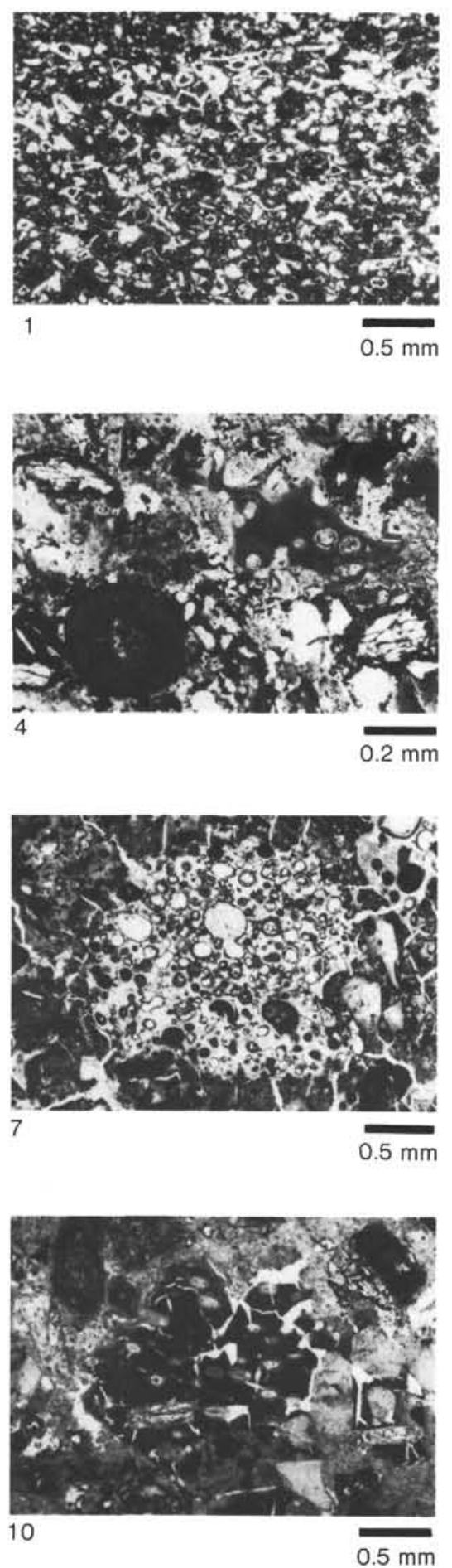
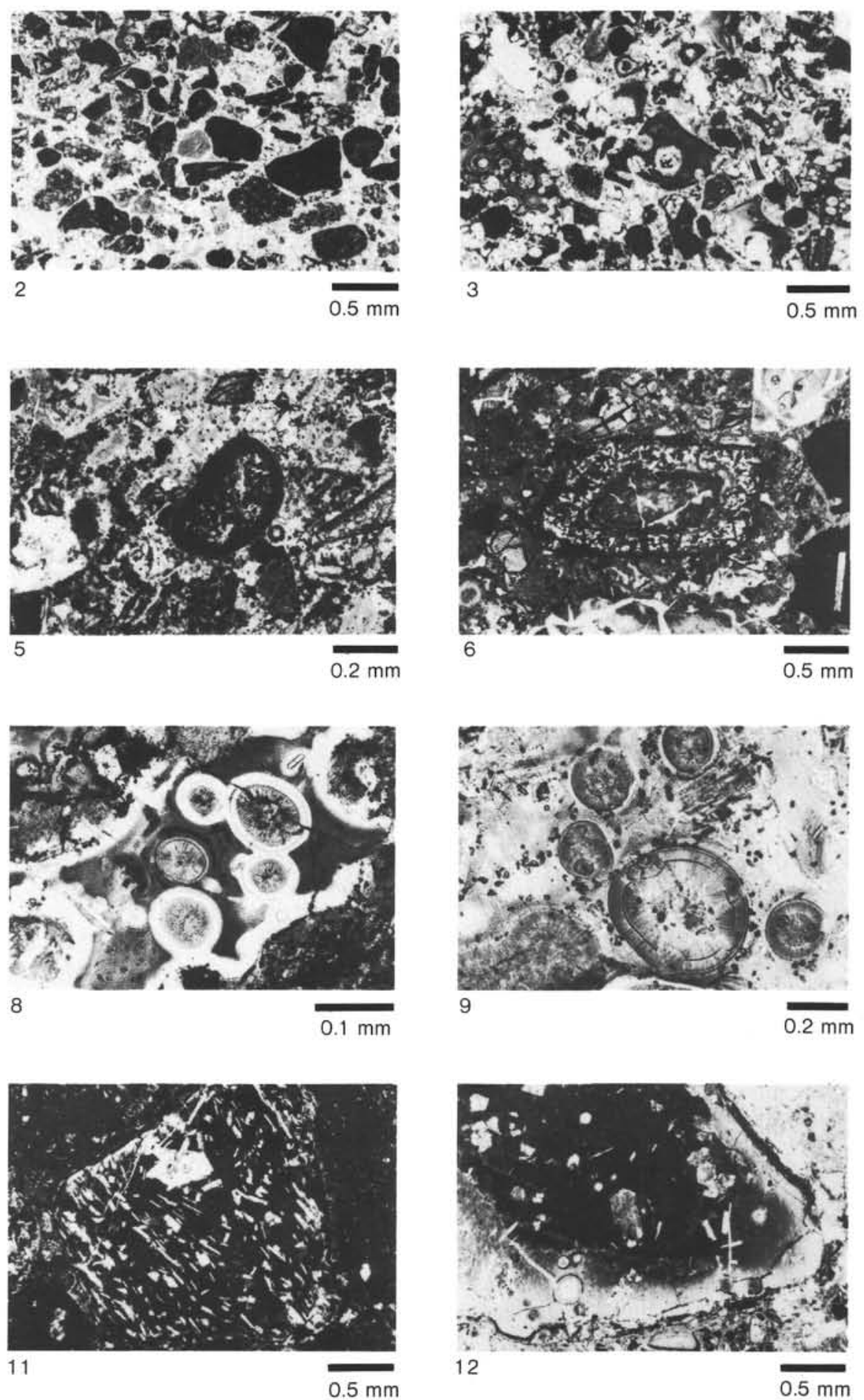

Plate 1. Photomicrographs illustrating petrographic and textural features of Site 585 (Leg 89) volcaniclastic sediments (ppl = plane polarized light; $\mathrm{xp}=$ crossed polars). 1. Fine-grained vitric tuff with shards partially replaced and rimed by smectite (xp), $585-42-3,48-50 \mathrm{~cm}$. 2. Coarsergrained volcaniclastic composed of variably phyric smectite-replaced glass shards and dark tachylite fragments (ppl), 585-45-2, 47-49 $\mathrm{cm}$. 3. Palagonitized vesicular shards in fine-grained smectite matrix (ppl), 585A-11-3,116-118 cm. 4. Vitric tuff with dark-rimmed clinopyroxene crystal fragments and concentric ooid nucleated on basaltic clast (ppl), 585-47-3, 128-131 cm. 5. Thin-walled oval ooid with a holocrystalline basalt clast core (ppl), 585-42-1, 19-21 cm. 6. Clear sideromelane, patchily replaced by granular smectite, enclosing a smectite-replaced glassy clast with alteration zoning (ppl), 585A-18-7, 61-64 cm. 7. Highly vesicular sideromelane shard (ppl), 585-46-4, 22-27 cm.8. Smectite zonation in a highly vesicular palagonitized shard; the change from narrow fibrous outer zones to coarser fibrous or platy interiors is typical of many infillings (ppl); 585-47-3, 128-131 cm. 9. Zonation of coarse fibrous smectite infilling vesicles; the inner zones show hemispherical growth from a point on the vesicle wall, and also appear to have been embayed by later internal deposits (ppl), 585-47-4, 136-139 cm. 10. Plagioclase-phyric vesicular smectite-replaced shard $(\mathrm{ppl}), 585 \mathrm{~A}-11-4,34-37 \mathrm{~cm}$. 11. Plagioclase-microphyric palagonitized vitric fragment; plagioclase is replaced by smectite (xp); 585A-19-1, 42-45 cm. 12. Plagioclase-phyric vesicular alteration-zoned palagonitized vitric fragment (ppl), 585A-14-2, 89$93 \mathrm{~cm}$. 

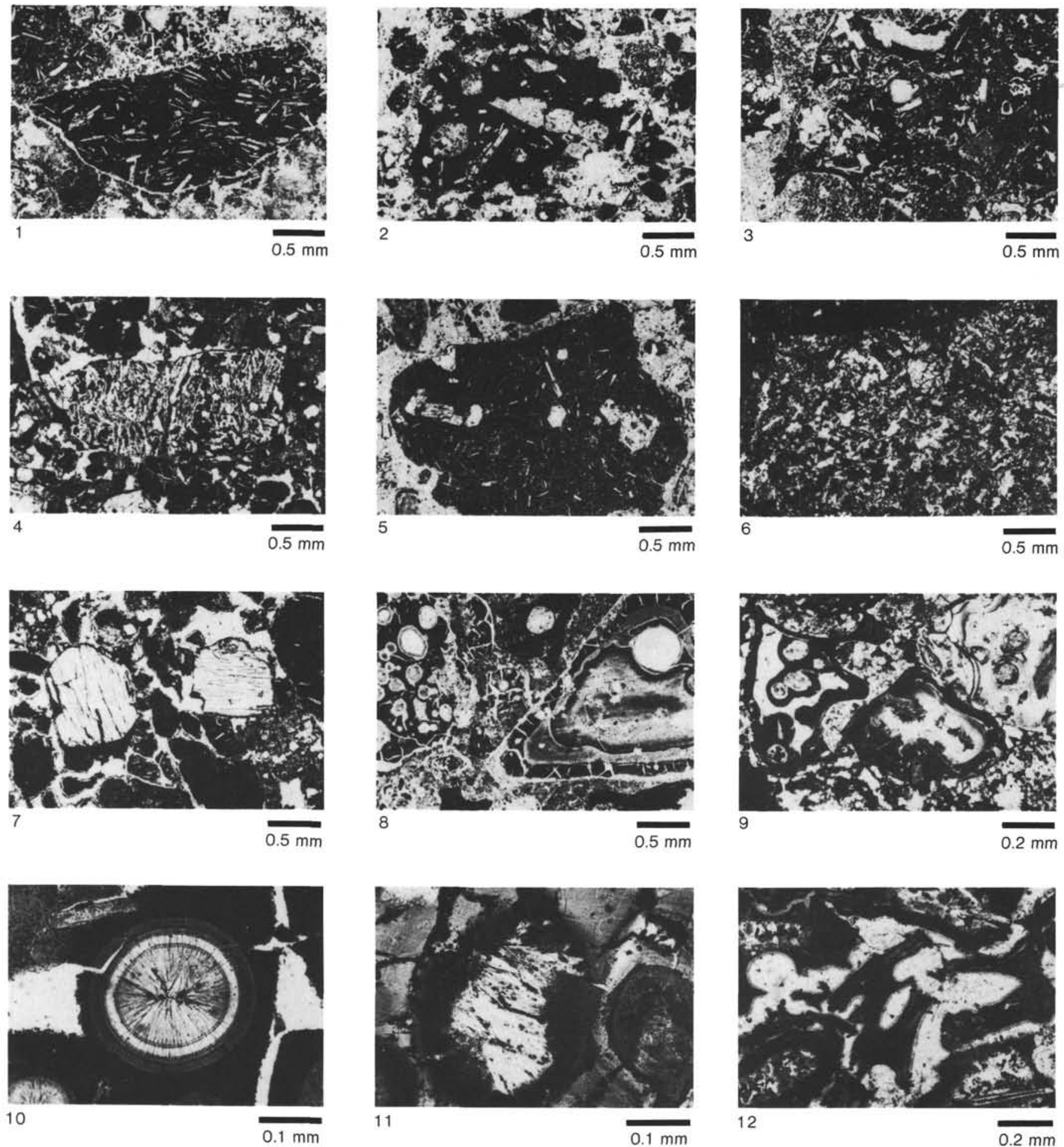

Plate 2. Photomicrographs illustrating petrographic and textural features of Site 585 (Leg 89) volcaniclastic sediments (ppl = plane polarized light; $\mathrm{xp}=$ crossed polars). 1. Plagioclase-microphyric tachylite clast $(\mathrm{ppl}), 585-48-1,108-110 \mathrm{~cm}$. 2. Celadonite replacing megaphenocrysts in tachylite clast (ppl), 585A-12-2, 86-89 cm. 3. Cuspate-margined hypocrystalline basalt clast with dark oxidized rim (ppl), 585-48-1, 43-47 cm. 4. Flow-oriented plagioclase and titanaugite in holocrystalline alkali basalt clast (ppl), 585-50,CC (3-5 cm). 5. Plagioclase-megaphyric vesicular holocrystalline basalt clast (ppl), 585A-13-5, 13-17 cm. 6. Part of a large clinopyroxene-microphyric holocrystalline basalt clast (xp), 585A$14-2,146-150 \mathrm{~cm}$. 7. Broken, subangular cleaved clinopyroxene crystals in a vitric-lithic tuff (ppl), 585-50,CC (9-12 cm). 8. Palagonitized vesicular vitric clasts; larger clast shows alteration zoning and development of small cracks in dark oxidized margin (ppl), 585-48-1, 108$110 \mathrm{~cm}$. 9. Plagioclase-phyric palagonitized shards with dark oxidized rims (ppl), 585-47-4, 112-115 cm. 10. Smectite zonation in vesicle (ppl), 585A-13-5, 13-17 cm. 11. Vesicle infilled with smectite grading to celadonite, with interior replaced by fibrous zeolite (ppl), 585A-18,CC $(26-27 \mathrm{~cm})$. 12. Palagonitized and smectite-replaced vesicular shards set in a zeolitic matrix (ppl), 585A-18-7, $46-50 \mathrm{~cm}$. 